\title{
CATTLE BUSINESS DEVELOPMENT STRATEGY IN THE REGENT OF BULUKUMBA, SOUTH SULAWESI PROVINCE
}

\author{
Machmud Achmad Ph.D \\ School of Management and Business, Bogor Agricultural University, \\ Indonesia. \\ Email: bpkmachmud@yahoo.com
}

\section{INTRODUCTION}

The term regional economic development strategy which is in accordance with economic slogan---of the people, by the people, and for the people-- is referring to the development strategy based on the utilization of natural as well as human resources in a sustainable way. The strategy is very suitable with government policy to foster the eastern Indonesian development. A total integration of agribusiness with various resources in the region cannot be avoided and the objectives of the development are totally directed to improve farmer's income, build an integrated agribusiness, make use of land resources in efficient and effective manner, and offer fair income distribution through out the villages.

In the context of agribusiness development, each region needs to develop its agribusiness activities by referring to the locally existing provisions be it the road, land, energy resources, human resources, or other resources. In South Sulawesi for example, there are abundant of resources in term of agro-ecological provisions such plantation, animal husbandry, food and horticulture. What the government has planned with PUTKATI, the abbreviation of farming and livestock development projects in eastern Indonesia, is very good as it is designed to implement the integration of livestock sub-sector with agriculture, horticulture crops, and with plantations system at nine regents of North Sulawesi, South Sulawesi and Maluku.

The main problems that have been encountered during the development of cattle business include human aspect in which the ranchers/cattle farmers have no skill and lack of competence to develop their livestock business. They only manage the ranch with family small scale. Besides, their livestock business is often focused only on sub-sector and they almost have no optimal role in the empowerment of the rural economy. 
The success of cattle business development in eastern Indonesia can be affected by various factors such as natural and human resources as well as technology. In addition, the unpredictable government policies have influenced decision makers' attitude in the rural level because the changing policy frequently hampered their livestock business development. Those factors can automatically in general perspective influence the efforts for improving the welfare of ranchers in the rural areas of eastern Indonesia provinces.

The aims of the study are (1) to identify factors that influence the development of cattle farming in Bulukumba, South Sulawesi, and (2) to select appropriate strategies for developing the livestock/cattle business in the region. Descriptive method in the form of case studies is applied in this study. Case studies used in this research are based on the farming development project (PUTKATI) in Bulukumba, South Sulawesi.

The data used in this study are divided into twofolds: primary data and secondary data. Primary data were obtained through questionnaires and interviews done to the officials and the people involved in the development of livestock in Bulukumba. Field observations are also done to cross check the data. Among primary data required in this study include the vision, mission and goals of economic development in Bulukumba, system data or agribusiness development pattern, and cattle business performance. The internal and external factors that influence the development of cattle farming in Bulukumba are investigated thoroughly in the research site. The secondary data were gathered from books and journal provided at the Directorate General of Livestock, Local Government of Bulukumba, and from other resources.

\section{LITERATURE REVIEW}

\section{DEFINITON OF CATTLE AGIBUSINESS SYSTEM}

The development of livestock business in Bulukumba, South Sulawesi had made a little progress as it shifted into agribusiness activities. Davis and Golberg in Pambudy, et al, (1999) suggest that agribusiness operationally is defined as the overall production and distribution of farm inputs, farm production activities (primary agriculture), storage, processing and distribution of agricultural commodities, the entire production and types of processed of agricultural commodities.

From the definition above, it can be interpreted that the development of cattle farming is part of the development of the agribusiness system. According to Saragih (2000) livestock 
agribusiness is a system that has four sub-systems: up-stream, on-farming, down-stream, and supporting institutions

Wiryokusumo (1999) on the other hand, defines agribusiness as a system of added value of the business activities to agricultural commodities in various phases, consisting of primary production activities that produce agricultural commodities. The secondary production is the process of primary production into value-added processed products in which its shape and quality fulfill the demand market. By passing the phases, the farmers can get added value of their goods.

The concept of cattle agribusiness that has been mentioned above can be applied to sub-business activities. In this context, there will be interrelation and mutual understanding among common business components such as cattle, plant, environment, and the consumers.

\section{CATTLE AGRIBUSINESS DEVELOPMENT}

In order to bridge the gap between supply and demand of livestock product and in conjunction with ASEAN free trade 2015, the government should find out new breakthrough in the policies and their implementations to speed up the growth of the livestock production. One of innovative solutions is the integration of potential resources supported the livestock business.

The policy of cattle agribusiness business in the long term (PJP II) is focused not only on the problem of cultivation (on farming activities or Bussiness oriented), but more concentrated on the development of agribusiness as a whole (Pambudy, 1999)

To implement the cattle agribusiness planning as mentioned in PJP II, the government has initiated basic principle called Cattle Business Trilogy (Breeding, Feeding, and Management). In a broader sense the trilogy includes the problem of seeding, feeding and managing system that should always meet the demands of the market (those things should be available according to the needs in required quantity, quality and schedule). The policies

made should be able to improve the income of the cattle farmers/ranchers, encourage diversification, improve their nutritional quality, and develop the products for export purpose (Pambudy, 1999).

\section{STRATEGIC MANAGEMENT}


According to Jauch and Glueck (1995), strategic management is a stream of decisions and actions which leads to the development of an effective strategy (or strategies) to help achieve corporate objectives. Furthermore, David (1997) defines that strategic management is an art and science of formulating, implementing and evaluating cross-functional decisions that enable an organization to achieve its objectives.

Strategic planning has nine processing steps which starting from the determination of mission and objectives, the development organization profiles, analysis of the external environment (micro and macro), the company's internal analysis, identification of strategic opportunities and threats, strategic decision making, strategy planning development, strategic implementation strategy, and the review and evaluation.

\section{PROJECT MANAGEMENT}

Project is a temporary activity with a specific purpose by using different resources (Reksohadiprodjo, 1993) while Ibrahim (1998) mentions that project is as a series of planned activities to get the benefit / advantages in the long run time. To achieve these objectives, the institution or company requires the resources and the project management.

Furthermore, Reksohadiprodjo (1993) defines project management as an attempt to plan, organize, direct, coordinate and supervise the activities in such a way that the project will run in accordance with the time schedule and allocated budget.

\section{METHOD OF ANALYSIS}

\section{INTERNAL - EXTERNAL ANALYSIS}

The strategy formulation process, according to David (1995) includes the objectives statement. These objectives should not be mutually contradictory either in part or as the whole and it should be in complement with the others. Some strategy purposes may change the formulation of corporate goals, accelerate the growth and increase profit, create a situation for the opportunities and threats analysis to further raise awareness of the company assets (strengths and weaknesses). Thus, internal and external environment are needed in the analysis process.

Internal-external environment analysis is an analytical strategy that can be used to overcome solution that is based on the external environment and internal situation. Through out this analysis, the company can develop some possible efforts to minimize threats and 
maximize strengths and weaknesses as well as opportunities for cattle business development in Bulukumba, South Sulawesi.

From the results of the internal analysis done by using IFE matrix (internal evaluation factor) and EFE matrix for external evaluation factor, the researcher found their total matrix scores. The combination of these two scores is shown in the internal-external matrix. David (1995) notes that in the matrix of internal-external (IE matrix) there are nine quadrants which are divided into three main strategy groups. Those groups are; growth strategy, hold and maintain strategy, and pruning strategy or harvest / divest strategy.

TOTAL SCORE OF INTERNAL FACTORS

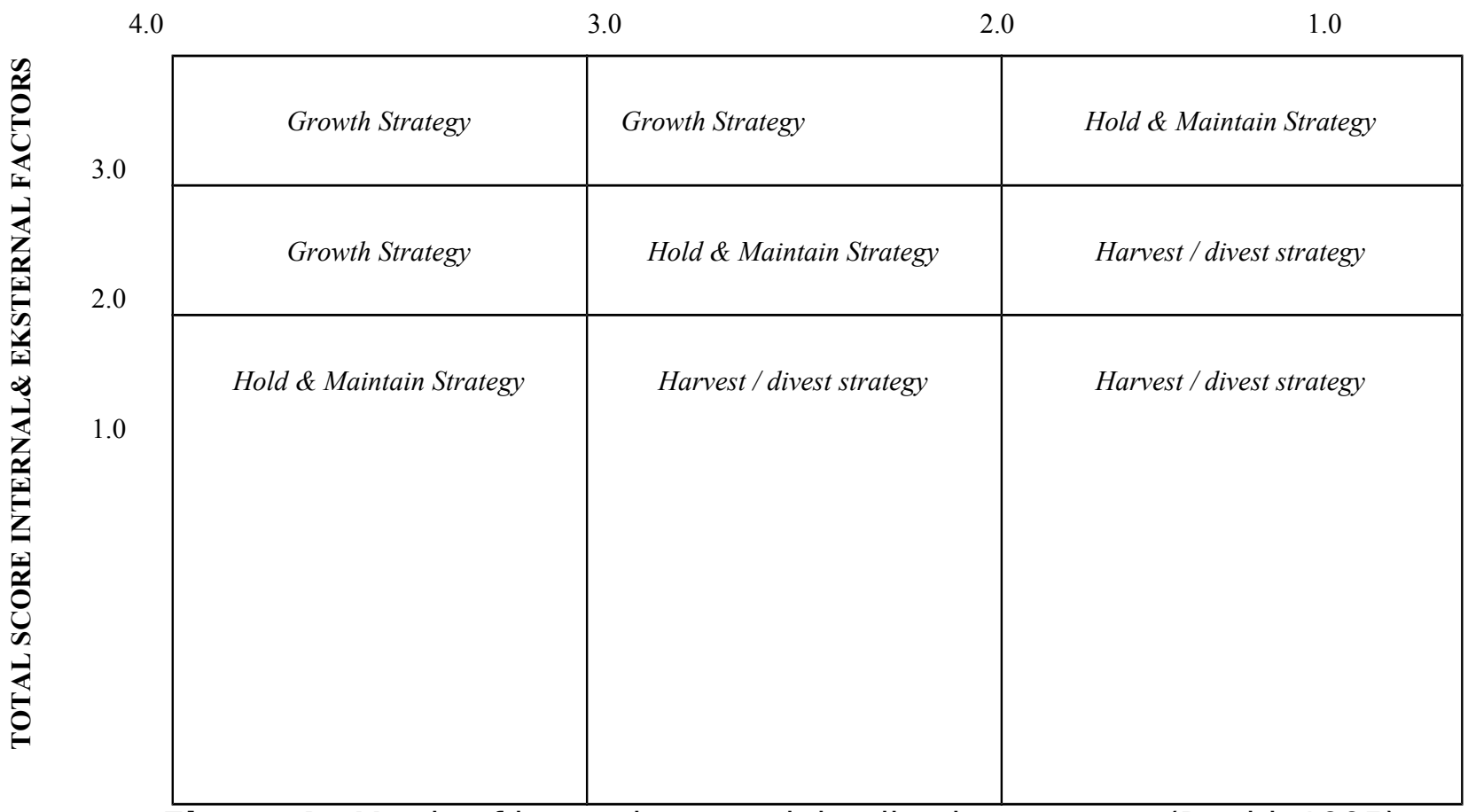

Figure 1 : Matrix of intemal-external implication strategy (David, 1995)

\section{ANALAYSIS WITH PAIR COMPARISON}

The results of internal and external analysis are preceded into alternative development by performing pair comparison of one component with the others in the same category and functionally related. The analysis that can be done by combining the strength and opportunities (SO strategy) are categories into; the analysis of all strengths to seize and exploit all opportunities as fast as possible, analysis of strengths and threats (ST strategy) and the use of force to overcome threats, analysis of weakness and opportunities (WO strategy) and the use of opportunities to minimize the weaknesses, and the analysis of weakness and threats (WT strategy) by the use of defensive activities to minimize weaknesses and avoid 
threats. Such pair comparison analysis is made in the form of a matrix of Internal-External (IE) and it is based on the results analysis of internal and external factors.

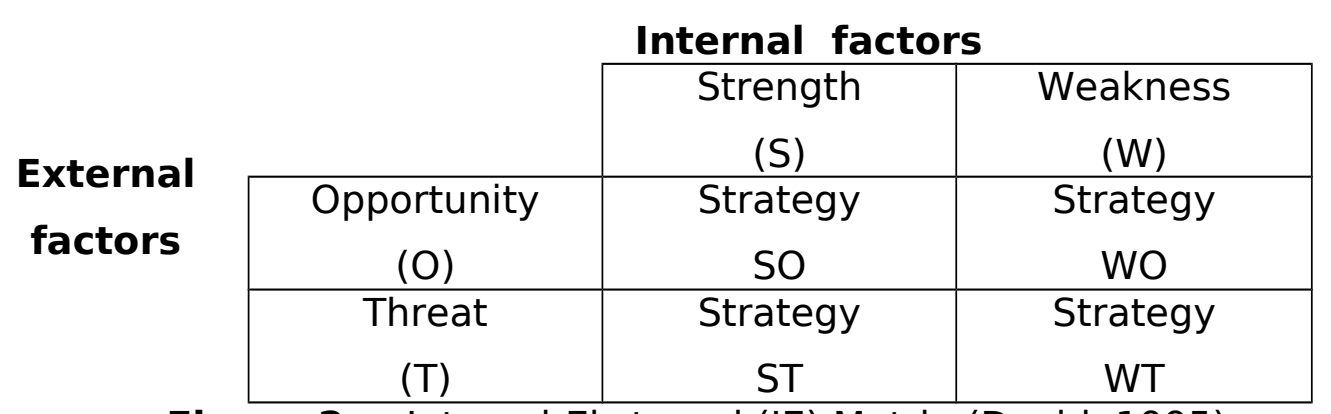

Figure 2 : Intemal-Eksternal (IE) Matrix (David, 1995)

\section{ANALITICAL HIERARCHY PROCESS (AHP)}

In order to select appropriate strategies for developing both agricultural farming and cattle farming at the same time in Bulukumba, South Sulawesi, the researcher used AHP method which aims at:

1. Deciding a policy after considering a wide range of criteria.

2. Establishing consistent policy

The analytical hierarchy process (AHP) is is a structured technique for organizing and analyzing complex decisions. It is a method that assists decision-makers in formulating a problem in an organized framework, identifying criteria and factors that influence and measure the interaction and interdependence between the factors and synthesize all the information to obtain a range of priorities. Priorities can be used to develop a variety of activities that support the application of main concern of the organization.

There are three principles in solving the problem with an explicit logical analysis:

1. Principles of constructing hierarchy

It is the first process in the AHP method, namely the identification of the observed reality.

It perceives the idea of using a particular set of knowledge and methods to see the root of any problems and its sub-sections related to the observed reality. 
2. The principle of establishing priorities

It is related to the person's ability to compare between two or more observed reality based on certain criteria and then to synthesize the assessment through imagination, logical process by using AHP. In this context elements are ranked according to its level of priorities which serves as a criterion called properties. The results of this defining process are priority vector elements. The final step in setting priorities is to give the weight of each vector either importance, or preference, or likelihood, or whatever factor is being considered by the decision makers.

3. The principle of logical consistency

Ensures that all the elements are grouped logically and consistently and rated in accordance with a logical criteria.

AHP is an analysis that can be used to understand the condition of the system and help the decision-making process. In its development, the AHP is not only used to determine the priority selection with multiple criteria, but extends its application as an alternative method to solve a variety of problems such as selecting a portfolio, and other cost benefit analysis.

According to Saaty (1991), AHP has several advantages, which can provide a single model that easily understand and flexible for a variety of unstructured problems. Moreover, it is considering the relative priorities of various system factors and allows to choose the best alternative based on the objectives to be achieved. AHP also can track the logical consistency of the considerations used in setting priorities. In this regard, the use of AHP is intended to choose the best alternative among several options for the livestock business development strategies to be implemented in Bulukumba, South Sulawesi.

In resolving problems with the use of AHP, there are several principles that must be understood, such as decomposition, comparative judgment, synthesis of priority, and logical consistency (Mulyono: 1996). 


\section{DISCUSSION AND CONCLUSION}

This research was conducted in Bulukumba, the region which is located at the southern tip of South Sulawesi province. Geographically, its location lies in latitude of $5^{0}$ south and $119^{\circ}$ east longitudes with total area of $1154.78 \mathrm{~km}$. The research was done from November 2000 to March 2001.

Respondents used in this study were selected by using non-probability sampling and purposive sampling. Respondents were selected with consideration of their knowledge and skills related to the subject area concerned. Respondents in this study were divided into two groups: a group of farmers / ranchers and policy makers. The data were analyzed by using excel program of MC Office 1998. For further processing, the AHP matrixes were used descriptively to formulate alternative strategy of SWOT.

\section{INTERNAL AND EXTERNAL ANALYSIS}

From the results of this study, it is found that the internal and external strengths and weaknesses factors had identified in Bulukumba as well as threat and opportunity aspects. Among the strengths items are (1) an extensive area of land, (2) geographic location, (3) suitable dry climate and (4) good irrigation system and the weaknesses are found as follows: (1) aspects of the capital (2) human resources. (3) cultivation techniques, (4). facility and infrastructure, (5) institutional and (6) linkages with other sectors.

Here are the opportunity aspects that affect the success of farming in Bulukumba; (1) very prospective market due to the development of new regions in eastern Indonesia, (2) local autonomy, (3) high demand of beef in the province of South Sulawesi, (4) the presence of foreign financial aid, (5) beef self-sufficiency program in 2005, and (6) government policies for the development of KTI. Meanwhile, the threat aspects that hinder the success of the cattle business in Bulukumba are; (1) the unpredictable of exchange rate,(2) inconsistency of political conditions, and, (3) high load of imported beef. 


\section{SWOT MATRIX}

The following are the results of the analysis of internal and external factors found in Bulukumba for further business development of livestock used in the pair wise comparison analysis, where the results of the analysis were made in the form SWOT matrix below;

\begin{tabular}{|c|c|c|}
\hline & $\begin{array}{l}\text { STRENGTHS -S } \\
\text { 1. Enough land for Cattle farming } \\
\text { 2. The availability of sufficient green } \\
\text { forage } \\
\text { 3. Suitable climate for farming } \\
\text { 4. The geographical position of } \\
\text { Bulukumba } \\
\text { 5. Good irrigation system }\end{array}$ & $\begin{array}{l}\text { WEAKNESSES - W } \\
\text { 1. Limited livestock development funds } \\
\text { 2. High credit interest rate } \\
\text { 3. Declined the quality of farmers' livestock } \\
\text { 4. High mortality of livestock } \\
\text { 5. High number of livestock lost } \\
\text { 6. Difficulty in target acquisition and dissemination of } \\
\text { livestock } \\
\text { 7. Lack of guidance to farmer groups } \\
\text { 8. Low inter-related of sub-sectors Integration } \\
\text { 9. Low project supervision } \\
\text { 10. Unstable Policy and political decision } \\
\text { 11. Lack of facilities holding ground in the district } \\
\text { 12. The lack of quarantine facilities } \\
\text { 13. Inadequate port } \\
\text { 14. Lack of linkages with the private sector, especially the } \\
\text { entrepreneurs } \\
\text { 15. Lack of linkages with the educational sector }\end{array}$ \\
\hline $\begin{array}{l}\quad \text { OPPORTUNITIES - O } \\
\text { 1. Increasing needs on beef } \\
\text { 2. Good market opportunity } \\
\text { 3. Foreign aid funds } \\
\text { 4. Self-sufficienc program in } 2005 \\
\text { 5. Regional autonomy } \\
\text { 6. Government policies for the } \\
\text { development of KTI }\end{array}$ & $\begin{array}{l}\text { SO STRATEGIES } \\
\text { 1. Development of extensive cattle farming in } \\
\text { Bulukumba, as the center of cattle farming } \\
\text { in South Sulawesi } \\
(\mathrm{S} 1, \mathrm{~S} 2, \mathrm{~S} 3, \mathrm{~S} 4, \mathrm{~S} 5, \mathrm{O} 1, \mathrm{O} 2, \mathrm{O} 3, \mathrm{O} 4,05, \mathrm{O} 6)\end{array}$ & $\begin{array}{l}\text { WO STRATEGIES } \\
\text { 1. Farmer Coaching group. to improve livestock farming } \\
\text { techniques } \\
\text { (W1,W2,03,04,05,06) } \\
\text { 2. Investment policy for the investors and low interest rates that } \\
\text { supported by integration of appropriate institution and regulation } \\
\text { (W3 W4 W9, W10.W11,01,02,O3,O4,05,06) } \\
\text { 3. Infrastructure development (W12,W13,W14,03,0506) }\end{array}$ \\
\hline
\end{tabular}




\begin{tabular}{|c|c|c|}
\hline & & $\begin{array}{l}\text { 4. Cooperation for cattle farming development (partnership) (W15, } \\
01,02,03,05,06)\end{array}$ \\
\hline $\begin{array}{l}\text { THREATS - T } \\
\text { 1. Unstable political conditions } \\
\text { 2. Unpredictable Rupiah rate } \\
\text { 3. High load of imported beef }\end{array}$ & $\begin{array}{l}\text { ST STRATEGIES } \\
\text { 1. Development of local cattle breeding (Bali } \\
\text { Cows) based on natural resources to reduce } \\
\text { high demand for imported beef } \\
(\mathrm{S} 1, \mathrm{~S} 2, \mathrm{~S} 3, \mathrm{~S} 4, \mathrm{~S} 5, \mathrm{~T} 1, \mathrm{~T} 2, \mathrm{~T} 3)\end{array}$ & $\begin{array}{l}\text { WT STRATEGIES } \\
\text { 1. Determining integrated farming development plan to increase } \\
\text { the livestock business knowledge, increasing the role of wife in } \\
\text { live stock farming, increasing productivity, improving } \\
\text { surveillance, making cattle business development plan (short } \\
\text { and medium-term). } \\
(\mathrm{T} 1, \mathrm{~W} 1,2,5,6,7,8,10,11,15,16, \mathrm{~W} 9, \mathrm{~W} 11)\end{array}$ \\
\hline
\end{tabular}




\section{CATTLE BUSINESS DEVELOPMENT STRATEGY IN THE REGENCY OF}

BULUKUMBA

\section{Proces Hierarchy Analysis ( AHP)}

The results of this study indicate that the most decisive factors in the successful development of the cattle business was the cattle business linkages between one and the other sectors (0.33). Linkages with other sectors such as agriculture, industry and trade are considered as main drive for cattle business success as there is a mutual relation between agricultural sector and livestock farming business--the provision of sufficient livestock forage has guaranteed its key success. In one hand, livestock manure can be used for fertilizer and in the other hand the cattle contribute significant energy to the agricultural farmers as they can substitute human labor needs.

The role of the Department of Agriculture was needed in the counseling and selecting superior commodities that can be developed by agricultural farmers. Similarly, the livestock business linkages with the industrial sector were supported by private parties in the chain of raw materials, for example, the use of fresh beef for canned beef industry. The role of the trade sector in the cattle business was regarded as the creator of livestock marketing both within and outside the region of Bulukumba. Thus, it will motivate cattle farmers to totally commit with their business.

The next determining factors influencing the success of business development in Bulukumba were infrastructure and supporting facilities. The results of the analysis hierarchy process (AHP) show the importance weight is 0:23 which is much lower than linkages with other factor of $0: 33$. From this figure, it can be interpreted that the success of the cattle farming is influenced by the association sectors such as agriculture, industry and trade, supporting facilities and infrastructure. At the moment, there are no facilities for animal quarantine, holding ground and adequate poultry shop. As a result, the quality of livestock distributed to the farmers is below standard or in a low quality. Besides, the location of the village - some villages are isolated from each other--- the limited means of transportation and bad road condition are responsible for difficulties in the distribution of livestock and its products.

Capital factors were also included as determining factor of livestock business development in Bulukumba case as indicated by weight of the capital factor of 0.13. Limited ability and lack of fund from Bulukumba local government in supporting the cattle farmers 
were classified as major problem. Since high interest rate of loan was charged to the farmer, then cheap capital was very difficult to find.

The results of the analysis of hierarchy process (AHP) show the same weight of 0:08 between the interests of the environment, availability of land and cultivation aspects. It suggests that those factors are equally important in the development of cattle farming in Bulukumba. Technological aspects and cultivation techniques were necessary for the improvement of the farmers' skill and knowledge in carrying out their business. This is because the cattle were not specifically granted to the farmers but they were used to raising animals by themselves. Those cattle were only given to poor farmers. Similarly, the carrying capacity of the environment and the availability of land can affect the success of livestock business development at Bulukumba. Another weakness is lack of qualified human resources.

The most active parties involved in this business were cattle farmers and Animal Husbandry Officers with the weights of 0:23 and 0:20. Cattle farmers were directly involved in the business. Their seriousness and high motivation have driven their cattle business reaches its success while Animal Husbandry Officers were usually responsible for supervision and counseling given to the farmers for the implementation of the program. Other party involved in the business is BAPEDA with the weight score of 0:19. They participated in the selection of livestock business location. The selection of the place for cattle business was done in accordance with general spatial planning of Bulukumba. Capital institutions like bank and cooperation were also one of the supporting factors which involved in the provision and distribution of funds needed for the cattle business. Similarly, the Directorate General of Livestock of central government only played its role in transferring technology to the cattle farmers.

Respective weight of importance score found for the objective aspects are; livestock business development of 0.31 , establishing livestock business of 0.30 , land resources utilization of 0:20, and the improvement of Bali cattle population of 0.19. To achieve these figures, various alternatives had been formulated. The weight of alternative strategy, mainly the provision of capital, got the weight score of (0.36) and business partnerships livestock of 0.28 . The figures suggest that capital procurement policy is an urgency aspect in conducting business partnerships. 
B

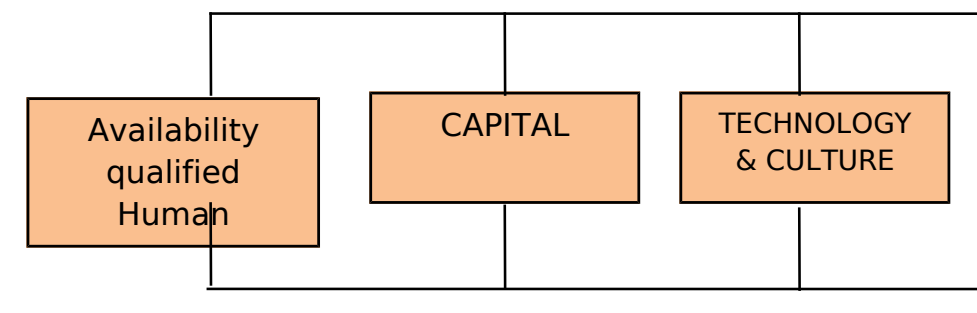

\section{INSTITUTION \&} REGULATION
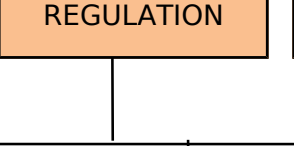

ENVIRONMENT SUPPORT/ LAND AVAILABILITY

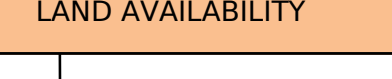
FACILITIES \&
INFRASTRUCTU
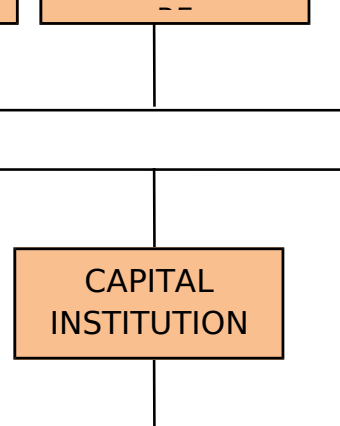

DIRECTORAT

E OF ANIMAL

HUSBANDRY

D

FARMERS

LOCAL

I
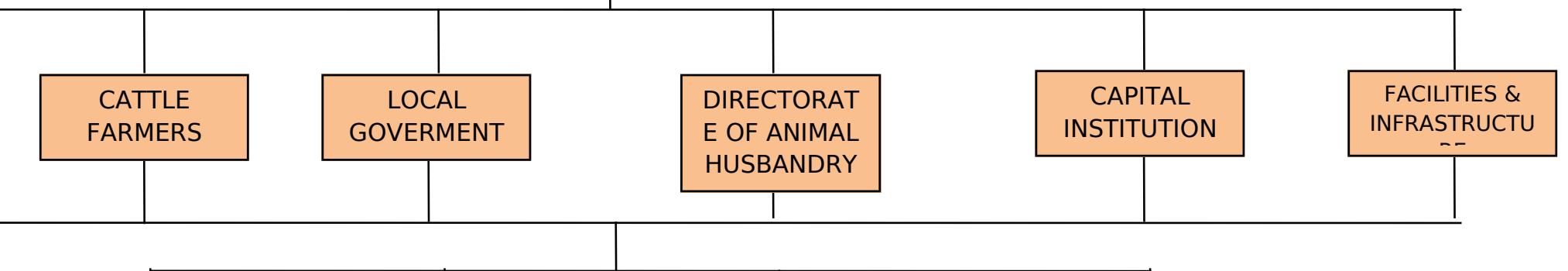

E

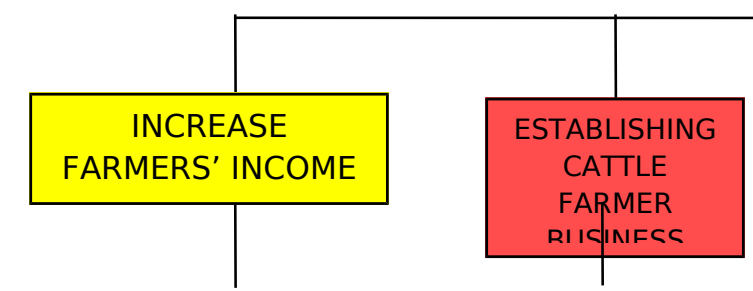

LAND UTILITY

INCREASING

BALI CATTLE

in
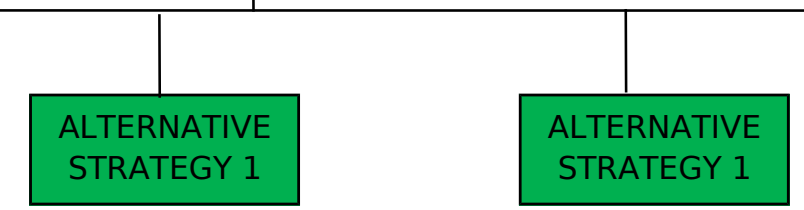

ALTERNATIVE

STRATEGY 1

NOTES :
A : FOCUS
B: DETERMINANT FACTORS

C: PARTICIPANTS INVOLVED

D: OBJECTIVES

E: ALTERNATIVE STRATEGY 
Picture : Main Hierarchy of Cattle Business Development of Bulukumba regency, South Sulawesi ( Hipotetik) 
DEVELOPMENT STRATEGIC PLANNING OF CATTLE BUSINESS AT BULUKUMBA REGENT

\begin{tabular}{|c|c|c|c|c|c|}
\hline NO & COMPONENTS & ALTERNATIVES & PRIORITIES & RECOMENDATION & ACTUATING PARTIES \\
\hline \multirow{4}{*}{1} & \multirow{4}{*}{$\begin{array}{l}\text { Alternative Strategies of } \\
\text { Cattle Business } \\
\text { Development }\end{array}$} & Capital & 1 & $\begin{array}{l}\text { Outsourcing,Policy on the loan and its interest } \\
\text { rate }\end{array}$ & $\begin{array}{l}\text { Directorate, } \\
\text { Local government } \\
\text { Banking Institutions }\end{array}$ \\
\hline & & Partnership & II & $\begin{array}{l}\text { Establishing cattle sub-business } \\
\text { In the form of group/unit }\end{array}$ & $\begin{array}{l}\text { Ranchers/cattle farmers } \\
\text { Private Businessman } \\
\text { Banking Institutions }\end{array}$ \\
\hline & & $\begin{array}{l}\text { Coaching of Farmers' group } \\
\text { Developing infrastructure and } \\
\text { Designing Cattle Business } \\
\text { Plan }\end{array}$ & III & $\begin{array}{l}\text { Increasing integrated coaching to the cattle } \\
\text { farmers, group empowerment; developing } \\
\text { infrastructure and transportation, giving } \\
\text { management training at the regency level, } \\
\text { providing consultation, and disseminating } \\
\text { technical details }\end{array}$ & $\begin{array}{l}\text { Ranchers/cattle farmers } \\
\text { Animal Husbandry officers } \\
\text { BAPPEDA } \\
\text { Educational Institutions. }\end{array}$ \\
\hline & & $\begin{array}{l}\text { Cattle business development } \\
\text { through intensification }\end{array}$ & IV & $\begin{array}{l}\text { Selecting the location of cattle business, } \\
\text { providing calf, and socializing sub-business } \\
\text { activities. }\end{array}$ & $\begin{array}{l}\text { Local government } \\
\text { represented by } \\
\text { Animal Husbandry officers } \\
\text { BAPPEDA, } \\
\text { Private Businessman } \\
\end{array}$ \\
\hline \multirow[t]{4}{*}{2} & \multirow[t]{4}{*}{$\begin{array}{l}\text { The purpose of cattle } \\
\text { business development }\end{array}$} & Increasing farmers' income & $\mathbf{I}$ & $\begin{array}{l}\text { (1).Determining integrated activities between } \\
\text { cattle farmers and agricultural farmers, }(2) \text {. } \\
\text { Establishing fresh beef processing industry, } \\
\text { (3). Establishing Animal market for } \\
\text { sustainable cattle productions market. }\end{array}$ & $\begin{array}{l}\text { Animal Husbandry officers } \\
\text { Department of agriculture } \\
\text { BAPPEDA } \\
\text { Banking Institutions } \\
\text { Private Businessman } \\
\end{array}$ \\
\hline & & Establishing cattle sub-business & II & $\begin{array}{l}\text { Designing cattle business development } \\
\text { pattern. }\end{array}$ & BAPPEDA \\
\hline & & Land utility & III & $\begin{array}{l}\text { Appointing the location of cattle business } \\
\text { based on the space management planning } \\
\text { and priorities scale system }\end{array}$ & BAPPEDA \\
\hline & & $\begin{array}{l}\text { Increasing Livestock } \\
\text { population }\end{array}$ & IV & Providing calf & $\begin{array}{l}\text { BAPPEDA, } \\
\text { Animal Husbandry officers }\end{array}$ \\
\hline
\end{tabular}




\begin{tabular}{|c|c|c|c|c|c|}
\hline & & & & & Banking Institutions \\
\hline \multirow{6}{*}{3} & \multirow{6}{*}{$\begin{array}{l}\text { Parties involved in the } \\
\text { cattle business }\end{array}$} & Cattle farmers & $\mathbf{I}$ & $\begin{array}{l}\text { Increasing knowledge, skill, motivation, and } \\
\text { cooperation in cattle business }\end{array}$ & $\begin{array}{l}\text { Animal Husbandry officers } \\
\text { Department of agriculture }\end{array}$ \\
\hline & & Animal Husbandry Officers & II & $\begin{array}{l}\text { Increasing coordination with related } \\
\text { institutions }\end{array}$ & $\begin{array}{l}\text { Animal Husbandry officers } \\
\text { Other related institutions }\end{array}$ \\
\hline & & BAPPEDA & III & $\begin{array}{l}\text { Evaluation and reorientation of the policies } \\
\text { related to the Cattle business development } \\
\text { including all aspects. }\end{array}$ & BAPPEDA \\
\hline & & Capital Institutions & IV & Giving Credit facilities with low interest rate & Banking Institutions \\
\hline & & $\begin{array}{l}\text { Directorate of animal } \\
\text { husbandry }\end{array}$ & $\mathbf{V}$ & $\begin{array}{l}\text { Supporting the farmers by issuing various } \\
\text { policies and rules to fulfill the outsourcing } \\
\text { funds from broad }\end{array}$ & $\begin{array}{l}\text { Directorate of animal } \\
\text { husbandry }\end{array}$ \\
\hline & & Educational Institution & VI & $\begin{array}{l}\text { Improving the educational institution } \\
\text { participation for training and updating cattle } \\
\text { farmers' skill }\end{array}$ & $\begin{array}{l}\text { Educational Institutions } \\
\text { Animal Husbandry officers } \\
\text { Cattle farmers }\end{array}$ \\
\hline \multirow[t]{4}{*}{4} & \multirow[t]{4}{*}{ Determinant factors } & Other sectors Linkage & $\mathbf{I}$ & $\begin{array}{l}\text { Increasing coordination with related } \\
\text { institution for marketing of the cattle } \\
\text { business products }\end{array}$ & $\begin{array}{l}\text { Animal Husbandry officers } \\
\text { BAPPEDA } \\
\text { Department of agriculture } \\
\text { Banking } \\
\text { Department of Industry } \\
\text { Department of commerce } \\
\text { Private businessman }\end{array}$ \\
\hline & & Facilities \& Infrasructure & II & $\begin{array}{l}\text { Developing Holding Ground, poultry shop, } \\
\text { other facilities and infrastructure including } \\
\text { animal market, road, bridges, processing } \\
\text { industry, harbor, etc }\end{array}$ & $\begin{array}{l}\text { BAPPEDA, Animal } \\
\text { Husbandry officers } \\
\text { Department of Industry } \\
\text { Department of commerce } \\
\text { Departemen of transportation }\end{array}$ \\
\hline & & Capital Institutions & III & Outsourcing & $\begin{array}{l}\text { Local government } \\
\text { Banking and private } \\
\text { businessman }\end{array}$ \\
\hline & & Institution \& Regulations & IV & $\begin{array}{l}\text { Monitor detail application of the plans with } \\
\text { detail guidance and technical assistances }\end{array}$ & Animal husbandry officers \\
\hline
\end{tabular}




\begin{tabular}{|l|l|l|l|l|l|}
\hline & & & \\
\cline { 3 - 5 } & $\begin{array}{c}\text { Environment support/Land } \\
\text { availability }\end{array}$ & $\mathbf{V}$ & Green conservation for the cattle production & $\begin{array}{l}\text { Animal husbandry officers } \\
\text { BAPPEDA } \\
\text { Educational Institutions }\end{array}$ \\
\cline { 3 - 5 } & $\begin{array}{c}\text { Availability \& qualified Human } \\
\text { Resource }\end{array}$ & $\mathbf{V I}$ & $\begin{array}{l}\text { Increase knowledge and skill in managing } \\
\text { cattle business }\end{array}$ & $\begin{array}{l}\text { Animal husbandry officers } \\
\text { Educational Institutions }\end{array}$ \\
\hline
\end{tabular}




\section{REFERENCES}

Capricorn Indonesia Consult (CIC). 1999. Prospek Perkembangan Usaha Ternak Di Indonesia. Indocomercial No.216. Jakarta.

David, F.R 1997. Strategic Management. Sixth Edition. Pretince Hall Inc. New Jersey

Direktorat Jendral Peternakan. 1996. Rencana Pelaksanaan Proyek Pengembangan Usahatani dan

ternak di Kawasan Timur Indonesia. Jakarta.

Direktorat Jendral Peternakan. 2000. Sambutan Direktur Jendral Peternakan. Pada Pembukaan Kongres GPPU dan Munas GAPPI 1. Jakarta.

Direktorat Jendral Produksi Peternakan. 2000. Evaluasi Pelaksanaan TA. 199/2000. Persiapan

Pelaksanaan TA. 2000 dan Rencana Proyek PUTKATI TA 2001. Materi Lokakarya Nasional Proyek PUTKATI. Denpasar.

Ibrahim, Yacob. 1998. Studi Kelayakan Bisnis. Rineka Cipta. Jakarta

IFAD. 1999. Studi Dampak Proyek PUTKATI Terhadap Kesejahteraan Keluarga Petani Tahun 1999. Jakarta.

Pambudi, R. 1999. Bisnis dan Kewirausahaan Dalam Sistem Agribisnis. Pustaka Kewirausaha Muda. Bogor.

Rangkuti, F. 1999. Analisis SWOT Teknik Membedah Kasus Bisnis. PT. Gramedia Pustaka Utama. Jakarta.

Resksohadiprodjo, S. 1991. Manajemen Proyek. BPFE. Yogyakarta.

Saaty, T.L. 1980. The Analytic Hierarchy Process: Planning, Priority Setting, Resource Allocation, ISBN 0-07-054371-2, McGraw-Hill

Saragih, B.1998. Agribisnis Berbasis Peternakan. Kumpulan Pemikiran. Pusat Studi Pembangunan Lembaga Penelitian. IPB Bogor

Sarinah, 1999. Kajian Pengembangan Industri Pengelolahan Hasil Perikanan Laut di Sulawesi

Tenggara. Geladikarya MMA-IPB.

UNOPS. 2000. Eastern Islands Smallholder Farming System and Livestock Development Project. Asia 
Office. Kualalumpur.

Wahyudi. 1999. Diktat Kuliah Metode Riset Agribisnis. Program Magister Manajemen Agribisnis.

Institut Pertanian Bogor.

Wahyudi., E Gumbira-Said dan A. Harizt Intan. 1998. Pedoman Geladikarya dan Penulisan Tesis.

Program Studi Magister Manajemen Agribisnis. Program Pascasarjana. Institut Pertanian

Bogor. 